\title{
Gender and housing policy in South Africa: Policy and practice in Bloemfontein ${ }^{1}$
}

\section{Anita Venter and Lochner Marais}

\begin{abstract}
Opsomming
In hierdie artikel word die toepassing van gendersensitiwiteit in die Suid-Afrikaanse behuisingsbeleidkonteks teen die agtergrond van internasionale veranderings rakende gender- en behuisingsparadigmas beoordeel. Die internasionale behuisingsbeleid en ontwikkelingsparadigmas in ontwikkelende lande het sedert die Tweede Wêreldoorlog ' $n$ aantal fases deurloop. Behuisingsfases sluit staatsgedrewe behuising, selfhelpbehuising, makro-ekonomiese hervorming en die instaatstellingbenadering in. Drie paradigmas het die genderteorie oorheers, naamlik Vroue in Ontwikkeling (VIO), Vroue en Ontwikkeling (VEO) en Gender en Ontwikkeling (GEO). Die Suid-Afrikaanse lae-inkomstebehuisingsbeleid bevat beginselverklarings oor genderbillikheid, maar daar is slegs beperkte riglyne vir die implementering van hierdie beginsels. Die artikel lewer teen hierdie agtergrond verslag oor die navorsing wat in die Mangaung Plaaslike Munisipaliteit (Bloemfontein) gedoen is oor hoe gendersensitief die implementering van die behuisingsbeleid is. Vier honderd en vyf vraelyste is in die proses voltooi, waarvan $50,6 \%$ uit huishoudings met vroue aan die hoof. Die artikel opper in wese drie argumente: eerstens, dat vrouens genoegsaam uit behuisingsvoorsiening voordeel geput het; tweedens, dat die beleid se inkrementele aard nietemin nie altyd vroue bevoordeel nie; en in die laaste plek het huishoudinge met sowel vroulike as manlike hoofde ' $n$ voorkeur uitgespreek vir ' $\mathrm{n}$ kleiner huis met beter dienste.
\end{abstract}

\section{- Ms A Venter}

- Dr L Marais

Centre for Development Support

University of the Free State

${ }^{1}$ An earlier version of this paper was presented at the XXXIII IAHS World Congress on Housing, September 2730, 2005, Pretoria, South Africa.

\section{INTRODUCTION}

Most literature focusing on gender in the context of the low-income housing field acknowledges that inadequate housing tends to have a greater impact on women, who spend more time in the home and its immediate environment, than on men (Moser, 1987; Moser \& Peake, 1994; Organisation for Economic Cooperation and Development (OECD), 1995; Rakodi, 1996; Sweetman, 1996; Fahra, 1999; Budlender, 2001; United Nations Centre for Human Settlements (UNCHS), 2000; Chant, 2003a \& 2003b). In addition, reflecting international trends, the number of femaleheaded households in South Africa is growing. In South Africa, female-headed households increased from $37,8 \%$ in 1996 to 41,9\% in 2001 (Statistics South Africa (SSA), 1998 \& 2003). Considering the growing number of female-headed households, as well as the emphasis on gender-related issues on a worldwide basis, there can be little doubt that gender should play a prominent role in policy considerations. South African housing policy has also been investigated from a gender perspective by means of a range of conceptual questions (Beall, 1996; Beall \& Todes, 2004). Despite the validity of these conceptual questions, however, very little empirical research has been conducted in this connection. (Some exceptions include Marais, 2002 and Ndinda, 2002 \& 2004.) This article represents an attempt to provide some preliminary evidence in this regard, on the basis of a case study conducted in the Mangaung settlement, the former black group area of Bloemfontein. Against this background, the article reports on research conducted on gender-sensitivity and the implementation of housing policy in Turflaagte, in the Mangaung Local Municipality (Bloemfontein). Essentially, we will advance two arguments: firstly, that women have benefited adequately from housing provision; and secondly, that the incremental nature of the policy nevertheless does not always benefit women.

This article is structured as follows: firstly, a clarification of relevant concepts will be given. Thereafter, international housing policy development and the corresponding development paradigms into which gender development falls will be discussed. Thirdly, a genderrelated evaluation of the South African housing policy will be provided; and fourthly, the methodology utilised for this study will be discussed. Lastly, the case study conducted in Turflaagte in the Mangaung Local Municipality will be critically investigated from a gender perspective.

\section{CLARIFICATION OF CONCEPTS}


The following concepts will be defined in order to avoid misinterpretation: gender; gender-sensitive; household; head of the household; low-income households, satisfaction; and incremental housing.

The term "gender" encompasses the socially defined sexual roles, attitudes and values that communities and societies consider to be appropriate for men and women (Abercrombie et al., 2000:149). Therefore, the gender of a person is culturally and socially constructed. To be gender-sensitive, according to Moser and Peake (1994:12), entails the ability to recognise women's different perceptions and interests arising from their different social location and different gender roles.

According to Statistics South Africa $(2004: 7,8)$, the head of the household is the main decision-maker, or the person who owns or rents the house, or the person who is the main breadwinner, as designated by the household. The head of the household can be either male or female. For the purposes of the study, the focus was on the gender of the person in whose name the title deed of the house was registered. The person in possession of the title deed of the house was, in the vast majority of cases, the head of the household. Low-income households, in the context of this study, refer to households whose combined income is less than R3 500 a month.

In terms of this study, "satisfaction" is defined as the degree of contentment with a specific house, as experienced within a particular residential, physical and social environment. This includes satisfaction with the specific housing attributes, as well as with the basic services provided (cf. Mehlomakulu \& Marais, 1999). The concept of incremental housing presupposes an ongoing improvement to the existing house and/or infrastructure, through the upgrading of the basic structure to suit the needs of the household (Pugh, 1991).

\section{INTERNATIONAL PARADIGMS AND CHANGE IN TERMS OF HOUSING AND GENDER}

Housing policy development and gender comprised separate research agendas up to the 1990s. Housing literature has no distinctive feminist perspective with regard to the housing debate in developing countries (Moser \& Peake, 1994:1-3; Beall \& Todes, 2004). Thus, for the purposes of this section focusing on the literature, gender will be placed in the context of the general development paradigm. Developmental shifts correlate with key shifts relating to housing policies. International housing policy and development paradigms in developing countries have undergone a number of phases since the Second World War. The interrelated housing policy phases are categorised in terms of state-driven public housing (early 1950s early 1970s); self-help housing and macro-economic reform (early 1970s - mid 1980s); the enablement approach (mid-1980s to the mid-1990s); and wholesector development (since the late 1990s). The development phases in terms of which gender is discussed include the Modernisation and Basic Needs paradigms, as well as the Women in Development (WID), Women and Development (WAD) and Gender and Development (GAD) frameworks. This section aims to provide an overview of how these two fields (housing and gender) became interlinked after the Second World War.

Between the early 1950s and the early 1970s, the main housing policy focus was on state-driven public housing. During this period, the role and responsibilities of the government were emphasised (Pugh, 1991, 1997, 2001; Marais, 2003:33). In essence, criticism of housing development from the 1950s to 1970s tended to focus on the inappropriateness of reassigning public housing policies from the developed world to the developing world (Moser \& Peake, 1994:4; Pugh, 1997; Berrisford et al., 2003:2). The housing phase of state-driven public housing correlates with the first dominant development paradigm of Modernisation (Moser \& Peake, 1994:4). The basic underlying assumption of the Modernisation theory was that modernity includes the adoption of many presumed attributes of Western society. During the development phase of Modernisation, urban research focused on the inequality and marginality of class and racial relations (Moser \& Peake, 1994:5). Gender issues were largely ignored in urban and housing policy until the 1970s; and the Modernisation period is generally regarded as a gender-blind period.

From the early 1970s to the mid-1980s, the World Bank rose to prominence with its adaptations of the self-help housing theories of Turner. The World Bank, with its theories of affordability, cost recovery and replicability, attempted to demonstrate that there were affordable low-cost and user-acceptable solutions to the problem of housing. The World Bank's policies were directed at state-assisted self-help housing in the form of sites and service projects and related in situ slum upgrading projects (Pugh, 1991,1997, 2001; Berrisford et al., 2003:3). The self-help housing phase (early 1970s - mid-1980s) correlates with the Basic Needs approach to development. Within the Basic Needs approach, the Women in Development (WID) and Women and Development (WAD) frameworks developed. From 1970 onwards, feminist research began to highlight gender differences in respect of urban needs (Moser, 1987:12; Moser \& Peake, 1994:8-10; OECD, 1995:28; Chant, 2003b:10). During the "Basic Needs" development phase, priority was given to the basic needs of all people, although women were still regarded as part of the household unit, and not necessarily as a group on their own (Beall \& Todes, 2004). Feminists began to question the relevance of "the household" as a unit without an adequate recognition of women and female-headed households. With the influence of the second-wave feminism of the late 1960s and the United Nations Decade for Women (1975-1985), the Women in Development (WID) framework, and consequently also the Women and Development (WAD) framework, developed in the 1970s. The WID framework played an important role in drawing attention to the neglect of issues affecting women in urban policy and planning. 
The Women and Development framework (WAD) emerged in the late 1970s and was centred on the basic needs of women (Moser \& Peake, 1994:10). Basic needs in the housing context include the provision of a housing structure, water, sanitation facilities and storm-water drainage. Nevertheless, for policy interventions to be meaningful to women in the long run, they should be coupled with the meeting of strategic needs, in order to address the deeper inequalities that lead to the subordination of women in societies (Moser \& Peake, 1994:21; Wickramasinghe, 2000:59).

The intensified global economic crisis and continuous urbanisation that occurred during the 1980s led to a decline in the delivery, maintenance and quality of essential urban services (Moser \& Peake, 1994:18; Keivan \& Werna, 2001). To assist the bankrupt economies of developing countries, the World Bank and the International Monetary Fund (IMF) developed macroeconomic reform packages of structural adjustment. In terms of structural adjustment, the focus shifted to increased participation of the private sector and the restructuring of housing subsidies (Pugh, 1997 \& 2001; Marais, 2003:37). The main critics of World Bank housing policies are neo-Marxists and dependency theorists such as Rod Burgess (Nientied \& van der Linde, 1985; Pugh, 1997, 2001; Ndinda, 2002:21; Harris, 2003). Some literature also reports that structural adjustment programmes have had a negative impact on women in cases where poverty is particularly severe in female-headed households (Moser \& Peake, 1994:19; Peters, 1996; Chant, 2003a:16; 2003b:39). Conversely, other research argues that structural adjustment policies have increased employment opportunities for women, although mainly within the more poorly paid sectors of society. The reallocation of labour, however, also entailed greater levels of unemployment for men, as well as a general decline in household income (Moser \& Peake, 1994:20; Beall, 1996; Wickramasinghe, 2000:6).

With the limited success of aided self-help and macroeconomic reform policies in meeting the demand for housing, the mid-1980s to the mid-1990s saw a shift towards the enablement approach. Enablement, as put forward by the United Nations Centre for Human Settlements (UNCHS) (cf. Berrisford et al., 2003:6), emphasised the productive contributions of settlements to the economy, as well as the role of cities. Special emphasis was placed on linking the roles of governments, markets, non-governmental organisations and community-based organisations. In terms of the enablement approach, the state was encouraged to create a favourable environment with a view to enabling communities to house themselves. Particularly popular was the idea of providing once-off housing subsidies to low-income earners to buy homes from the private sector (Gilbert, 2004). The enablement approach saw an increased focus on women and urban development (Rakodi, 1996). Gender-related criticism, raised in the late 1980s regarding the housing policies of the World Bank, elaborated on criticism that had already been voiced in the 1970s (Moser \& Peake, 1994:8). Housing policies should not only focus on economics in order to define housing needs, but also on gender differences. In the enablement phase of housing policy, special emphasis was placed on the Gender and Development (GAD) framework. Whereas WID and WAD are rooted in the liberal feminist principles of inequality, GAD is embedded in socialist feminist theories of oppression, and evolved during the third wave of Western feminism (Moser \& Peake, 1994:1-3; Wickramasinghe, 2000:42). The GAD theory, similar to the principles of feminism in the neo-Marxist paradigm, identifies the unequal power relations between women and men as the main reason for inequality. Society legitimises a family and housing system in which men are assigned dominant, and women subordinate, roles. Consequently, women have less access to and control over resources than men. The GAD approach urges transformative change in gender relations in order to achieve gender equality and equity (Moser \& Peake, 1994:11). According to Moser and Peake (1994:8-21), the gender constraints that limit women's access to housing include property and inheritance rights, eligibility criteria, income, education and cultural restrictions. These constraints affect women, not only in terms of access to housing, but also in terms of the sustainability of their living conditions. However, in support of Wickramasinghe's (2000:66) point of view, it must be noted that it is doubtful whether the GAD framework has the capacity to address oppressive power relations based on class, race and culture in developing countries.

Finally, from the late nineties to the present, there has been an increased focus on poverty alleviation through whole-sector development. Whole-sector development is characterised by a shift away from the project-by-project approach towards low-income housing solutions that are supportive of pro-poor development, environmentalism and whole-sector housing changes (Pugh, 2001). Since the 1990s, both the World Bank and the United Nations have been much more active in promoting gender equality in urban development. As in the case of housing policy, the development paradigm has also evolved in such a way that gender now comprises a greater part of the research agenda of enablement, anti-poverty and sustainability. However, from international experience, it is evident that, even if laws and policies recognise women's equal rights to housing, such laws and policies are still very difficult to implement in practice (Kothari, 2003:1; Benschop, 2004:5).

\section{GENDER AND HOUSING POLICY IN A SOUTH AF- RICAN CONTEXT}

International neo-liberal trends with regard to housing policy development had an impact on the content and development of low-income housing policy in South Africa. Reflecting international trends, the South African housing policy also incorporated the concepts of security of tenure, enablement, incrementalism, targeted subsidies and an emphasis on the role of the private sector in housing delivery. The influence of the World Bank is particularly prominent (cf. Bond \& Tait, 1997; Gilbert, 2002; Marais, 2003:53; Berrisford et al., 2003:2). 
The South African housing policy and programme was introduced in 1994. The current framework for housing policy is set out in the White Paper on Housing (Republic of South Africa, 1994). The White Paper on Housing, in accordance with the South African Constitution, stipulates that new policies should be sensitive to the removal of discrimination in respect of gender, race and religion. In contrast to international policy guidelines, the White Paper on Housing is quite explicit with regard to the eligibility criteria in respect of who the end-beneficiaries should be. The housing subsidy scheme targets South African citizens who are most in need of shelter, and who earn less than R3 500 per month. In addition, according to the Breaking New Ground comprehensive housing plan, effective as from April 2005, a new subsidy band has been created for middle-income-level households earning between R3 500 and R 7000 per month (Department of Housing, 2004:9).

The subsidy scheme is not only based on income, but also requires that beneficiaries should be older than 21 years of age, and that they should be married or co-habiting and / or single with financial dependants. Low-income earners who have received any previous form of subsidy from the government are excluded from the current housing subsidy scheme (Republic of South Africa, 1994:38). The various types of subsidies available to low-income earners in urban areas include project-linked, individual, institutional and consolidation subsidies, as well as People's Housing Process (PHP) subsidies (Public Service Commission, 2003:9). The amount of subsidy received by the endbeneficiary is dependent on the joint income of spouses (Republic of South Africa, 1994:41). The maximum subsidy value available to the very poor in 2005 was R31 929. In addition, government will assist middle-income households earning between R3 500 and R 7000 per month by providing a credit- and savings-linked subsidy for their houses (Department of Housing, 2004:25). The subsidy can be used for one or more of the following: a serviced site; a serviced site with a basic structure; in situ upgrading of a community neighbourhood; and/or a portion of the cost of either a house or a flat. Since the nature of the current housing policy is incremental, the subsidy generally only provides for a rudimentary house (Republic of South Africa, 1994:40). Although the national government developed the housing policy in 1994, it is the responsibility of provincial governments to implement the policy.

According to the White Paper on Housing, government has specifically identified the need to support the role of women in the housing delivery process (Republic of South Africa, 1994:21). From a gender perspective, it seems as if the housing policy, with its subsidy scheme objectives, promotes gender equality - no policy-related obstacle prevents women from becoming home-owners. However, the government's housing policy, despite being favourable to women, is not without problems. An evaluation of the housing subsidy scheme indicated that housing policy directives specifically focusing on gender equity are largely neglected in most provinces (Public Service Commission, 2003:58). Gauteng is the only province that has specific gender-related housing policy objectives in place (Richards \& Rust, 2002; Public Service Commission, 2003:58). The Women and Housing Policy of Gauteng is strongly reminiscent of the international Women in Development (WID) and Gender and Development (GAD) paradigms. Essentially, the aim of this policy is to balance a Basic Needs approach with a strategic, as well as an education and training approach (Richards \& Rust, 2002:4). Gender-related criticism has also been raised concerning the eligibility criteria and the incremental nature of the housing policy. Research studies (Ndinda, 2002:86; Marx, 2003:307; Public Service Commission, 2003:18) have criticised the exclusion of young adults aged between 18 and 21 years from the subsidy scheme. The age restriction of 21 years limits the access of young women to housing. This is a serious shortcoming, if the fact that half of the pregnancies in South Africa occur among women under the age of 21 is taken into account (Parnell, in Marx, 2003:307). The requirement in respect of dependants could also result in a situation where women who are desperately in need of housing resort to falling pregnant in order to qualify for a housing subsidy.

The relevancy of the neo-liberal ideology with regard to the housing policy and gender equality can be questioned. An analysis of the housing subsidy scheme reveals a lack of gender-sensitivity in general (see Khan \& Thurman, 2001:41; Marais, 2002; Public Service Commission, 2003: 18, 58; Marx, 2003:306307). In addition, the incremental nature of the housing policy has been investigated from a gender perspective (Ndinda, 2002:91 \& 2004). For instance, as Ndinda (2004) argues, policy objectives assume that women can incrementally contribute to the housing process without placing strain on their multiple roles in the home and community. The incremental policy prerequisite has an especially negative impact on singleheaded, female-headed families with young children, as well as on elderly female-headed families.

\section{EVIDENCE FROM BLOEMFONTEIN}

The emphasis will now shift to the case study in Bloemfontein. However, before the main findings of the survey are discussed, an overview of the methodology followed in gathering the empirical information will be provided.

\section{Methodology}

The Housing Directorate of the Mangaung Local Municipality assisted with the sampling for this study. The Housing Directorate provided a list of all the lowincome housing projects conducted in Turflaagte between 2000 and 2004, involving 1665 households. This list contained information regarding the age, gender, marital status and number of dependants of the housing beneficiaries in Turflaagte. It also contained the site numbers of the low-income housing projects. From this list, it was possible to draw a gender- 
representative sample in terms of heads of households in the survey area.

Four fieldworkers, proficient in the languages spoken in the Mangaung Local Municipality and familiar with the area, were trained by the researcher. Two of the fieldworkers were also from the community in which the survey was conducted. Each fieldworker was given a list indicating the selected stand numbers of households to be interviewed. Fieldworkers were also provided with a map that indicated where all the stands were located. The fieldworkers collected data during September 2004 by means of a structured household questionnaire. A total of 405 households were interviewed. Of these, $50 \%$ were households headed by women. Two methods of quality control were used. Many respondents with a contact number provided their number voluntarily, and it was therefore possible to contact them telephonically. The second method was to compare the information that had been provided by the Free State Department of Local Government and Housing with the information received from the fieldworkers.

The questionnaire was divided into five sections. The first section indicated the stand or plot number of the house, as well as the type of household services available on the stand. The following two sections focused on obtaining demographic and socio-economic information relating to the household, such as age; the number of people, including dependants, who resided on the stand at the time of the interviews; the number of years during which the respondents had been residing in their low-income house; the respondents' marital status; their highest formal education; as well as their income and employment profile. The fourth section focused on obtaining information about the physical attributes of each house, the respondents' degree of satisfaction with the house, as well as any improvements made and/or envisaged. The final section contained questions concerning the degree of satisfaction with household services. Aspects relating to the housing structure that the respondents were required to assess included: roof condition; floor covering; walls; damp conditions during rain; natural light in the house; the number of rooms and windows in the house; the temperature in summer and winter in the house; ventilation in the house; the size of the house and stand; their settlement, Turflaagte; privacy in the house; and the degree to which they felt safe in the house. The criteria chosen were broadly based on other research studies (Tomlinson, 1999; Public Service Commission, 2003:91,96; Zack \& Charlton, 2003:54) in which beneficiaries' satisfaction with their housing product was assessed. The degrees of satisfaction with the housing were differentiated by means of a 4-point Likert scale. Respondents were required to choose one of the following options for each item: very satisfied, satisfied, somewhat dissatisfied and not satisfied at all. For the purpose of analysis, the answers indicating "very satisfied" and "satisfied", as well as those indicating "somewhat dissatisfied" and "not satisfied at all", were combined. The evaluation of the satisfaction levels was then based on these combined figures.

In order to make statistical analysis possible, open and closed questions were given a numerical value. Data analysis was accomplished by using the SPSS (Statistical Package for the Social Sciences) software and the Microsoft Excel programme.

\section{A brief socio-economic overview}

Before a more in-depth assessment of the empirical results can be carried out, a brief socio-economic comparison between female- and male-headed households is required. Significant gender-related differences were observed between the socioeconomic statuses of female- and male-headed households (Table 1).

The data in Table 1 point to the fact that there is a higher level of poverty among female-headed households than among male-headed households. Gender differences were noticeable between female- and male-headed households in respect of the following criteria: income of less than R750 a month $(67,5 \%$ vs 42, 5\%); unemployment or receiving a social grant (64,9\% vs 44,7\%); and low education levels (62,9\% vs $47,7 \%)$. In addition, it can be assumed that the circumstances of women in female-headed households are particularly constrained, as most female heads were also the only breadwinners $(24,7 \%$ vs $52,4 \%)$, in contrast to their male counterparts. The socioeconomic survey results reflect gender-related differences with regard to the socio-economic living conditions of women, which are similar to the gender differences experienced in the rest of the developing world. Historically, women's domestic responsibilities have been an obstacle to their full participation in the eco-

TABLE 1: DEMOGRAPHIC AND SOCIO-ECONOMIC PROFILE OF RESPONDENTS

\begin{tabular}{|l|c|c|c|c|c|c|c|c|}
\hline Demographic and socio-economic & \multicolumn{4}{|c|}{ Female-headed } & \multicolumn{4}{c|}{ Male-headed } \\
\cline { 2 - 9 } profile & $\boldsymbol{N}$ & $\%$ & Total & $\%$ & $\boldsymbol{N}$ & $\%$ & Total & $\%$ \\
\hline $\begin{array}{l}\text { \% of households earning less than } \\
\text { R750 a month }\end{array}$ & 131 & 67,5 & 194 & 100,0 & 85 & 42,5 & 200 & 100,0 \\
\hline $\begin{array}{l}\text { \% of respondents unemployed, or re- } \\
\text { ceiving social grants or pensions }\end{array}$ & 133 & 64,9 & 205 & 100,0 & 89 & 44,7 & 199 & 100,0 \\
\hline $\begin{array}{l}\text { \% of respondents with more than one } \\
\text { breadwinner in household }\end{array}$ & 41 & 24,7 & 166 & 100,0 & 100 & 52,4 & 191 & 100,0 \\
\hline $\begin{array}{l}\text { \% of respondents with low education } \\
\text { levels (lower than grade 8) }\end{array}$ & 129 & 62,9 & 205 & 100,0 & 95 & 47,7 & 199 & 100,0 \\
\hline
\end{tabular}

** The missing values were not included in the statistics 
nomic sector (Chant, 2003a:7; Ndinda, 2002:49). In addition, women's disadvantages in terms of accessing education and training still prevent them from profiting from new economic opportunities, and they continue to be discriminated against in the labour market (Latigo, 2004:7).

\section{Do women benefit from the subsidy?}

Since it is very difficult to measure the gender impact of the provision of low-income housing, housing departments attempt to measure gender impacts in terms of the percentage of female-headed households that are benefiting from a subsidy (Budlender, 2001:56). The National Department of Housing (2003) indicated that $39 \%$ of all housing subsidies that were allocated up to December 2002 went to femaleheaded households. However, between 2000 and 2004 , more female- than male headed $(55,4 \%$ vs $44,6 \%$ ) households in Turflaagte were subsidy beneficiaries. The case study also shows that single-femaleheaded households (Table 2 ) benefited from the subsidy scheme.

As indicated in Table 2, considerably fewer female respondents than male respondents were married or co-habiting $(19,6 \%$ vs $77,0 \%)$. The foregoing figures reflect positively on the implementation of the housing policy, in terms of benefiting women in the particular case study in the Mangaung Local Municipality. However, it should be mentioned that at the time of the case study, no statistics existed with regard to either the number of housing applicants or their gender status (Free State Department of Local Government and Housing, 2004:11). Consequently, it was not possible to compare the gender of applicants with the gender of the actual beneficiaries.

\section{Satisfaction levels}

Respondents were generally dissatisfied with the physical structure of their houses. Some gender differences are noticeable in this regard (Table 3 ).

Female respondents were more dissatisfied than male respondents with regard to the condition of the walls (81,9\% vs $68,5 \%)$; damp conditions $(79,7 \%$ vs $67.5 \%)$; and the roof of the house $(69,5 \%$ vs $50,5 \%)$. The low levels of satisfaction among female respondents with regard to the physical structure of their houses could be an indication that, since women spend more time at home, inadequacies pertaining to the house tend to be experienced more intensely by women. The dissatisfaction with these physical aspects could also be a reflection of women's general lack of money, skill and physical strength to repair these inadequacies. The male respondents were more dissatisfied with aspects relating to the size of the house, as well as the temperature experienced in the house (Table 3 ). It seems as if the aspects with which the male respondents were dissatisfied, mainly comprised those attributes over which they had less control in terms of possible reparations or change. The low levels of satisfaction with the housing structure are particularly alarming in the light of the fact that most of the low-income houses in Turflaagte are relatively new, having only been built after 2000 .

\section{Incremental housing}

As already mentioned, South African housing policy is essentially aimed at providing a "starter house". The household is then required to incrementally upgrade the housing structure over a period of time. Specific attention was devoted to gaining an understanding of the incremental upgrading process (Tables $4 \& 5$ ).

Before the results of Table 4 are discussed, it should be mentioned that the female-headed households that had made one or more improvements, were fewer in number than the male-headed households that had made similar improvements $(59,5 \%$ vs $88,5 \%)$. The fact that such a large percentage of the male respondents had made improvements in respect of the above-mentioned aspects of their houses, may indicate that, compared with the women, the men had more finances and technical skills to make the improvements envisioned in terms of the incremental approach. The three most important types of improvements that female respondents had made to their lowincome houses were: painting of the house $(24,9 \%)$; plastering of walls $(23,9 \%)$; and the installation of burglar bars and security gates $(22,4 \%)$. Even though the female respondents prioritised these three improvements, there were still more male respondents, percentage-wise, who had actually made such improvements. However, a significant difference was noticeable in terms of the fact that more female respondents than male respondents $(10,7 \%$ vs $2,5 \%)$ had installed doors. This could point to the high priority that female respondents accord to privacy. Slightly more female than male respondents had also added extra windows $(10,2 \%$ vs $7,0 \%)$. Other improvements made by female respondents included improvements to the floor covering $(10,7 \%)$; electricity connections $(10,7 \%)$; and gardening $(5,4 \%)$. The three most important types of improvements that male respondents had made to their houses were improvements to the floor covering $(68,0 \%)$; the installation of burglar bars or security gates $(46,5 \%)$; and painting of the house $(42,0 \%)$. Floor-covering and safety measures are very practical improvements aimed at making one's life more comfortable. Other improvements made by male respondents included plastering of the house $(27,5 \%)$; gardening $(18,0 \%)$; and installation of electricity connections $(11,5 \%)$.

\section{Envisaged improvements to the basic housing structure}

Respondents of the households interviewed were asked what improvements they would make if they were in a position to change or improve any physical aspects of their houses (Table 5).

Fewer female than male respondents $(60,0 \%$ vs $89,0 \%$ ) specified the improvements that they envisaged. As indicated in Table 5, both female- and maleheaded households expressed their desire to enlarge their houses. It is worth mentioning that, although 
TABLE 2: $\quad$ MARITAL STATUS OF RESPONDENTS

\begin{tabular}{|l|c|c|c|c|c|c|}
\hline \multirow{2}{*}{ Marital status } & \multicolumn{2}{|c|}{ Female-headed } & \multicolumn{2}{c|}{ Male-headed } & \multicolumn{2}{c|}{ Total } \\
\cline { 2 - 7 } & $\boldsymbol{N}$ & $\mathbf{\%}$ & $\boldsymbol{N}$ & $\mathbf{\%}$ & $\boldsymbol{N}$ & $\%$ \\
\hline Single & 40 & 19,6 & 12 & 6,0 & 52 & 12,9 \\
\hline Married / living together & 38 & 18,6 & 154 & 77,0 & 192 & 47,5 \\
\hline Divorced / separated & 64 & 31,4 & 20 & 10,0 & 84 & 20,8 \\
\hline Widowed & 62 & 30,4 & 14 & 7,0 & 76 & 18,8 \\
\hline Total & 204 & 100 & 200 & 100 & 404 & 100 \\
\hline
\end{tabular}

* The missing values were not included in the statistics

TABLE 3: $\quad$ DISSATISFACTION WITH HOUSES ACCORDING TO GENDER

\begin{tabular}{|l|c|c|c|c|c|c|c|c|}
\hline \multirow{2}{*}{$\begin{array}{l}\text { Dissatisfaction with aspects of } \\
\text { house }\end{array}$} & \multicolumn{4}{|c|}{ Female-headed } & \multicolumn{4}{c|}{ Male-headed } \\
\cline { 2 - 10 } & $\boldsymbol{N}$ & $\%$ & Total & $\%$ & $\boldsymbol{N}$ & $\%$ & Total & $\%$ \\
\hline Condition of walls & 167 & 81,9 & 204 & 100 & 135 & 68,5 & 197 & 100 \\
\hline Damp conditions in house & 161 & 79,7 & 202 & 100 & 135 & 67,5 & 200 & 100 \\
\hline Roof & 139 & 69,5 & 200 & 100 & 100 & 50,5 & 198 & 100 \\
\hline Summer temperature in house & 101 & 49,8 & 203 & 100 & 116 & 58,0 & 200 & 100 \\
\hline Winter temperature in house & 113 & 55,9 & 202 & 100 & 144 & 72,4 & 199 & 100 \\
\hline Number of rooms in house & 69 & 34,0 & 203 & 100 & 115 & 57,8 & 199 & 100 \\
\hline
\end{tabular}

** The missing values were not included in the statistics

TABLE 4: $\quad$ ACTUAL IMPROVEMENTS TO THE BASIC HOUSING STRUCTURE IN TURFLAAGTE, 2004

\begin{tabular}{|l|c|c|c|c|c|c|}
\hline \multirow{2}{*}{ Type of improvements made } & \multicolumn{2}{|c|}{ Female-headed } & \multicolumn{2}{|c|}{ Male-headed } & \multicolumn{2}{|c|}{ Total } \\
\cline { 2 - 7 } & $\boldsymbol{N}$ & $\mathbf{9}$ & $\boldsymbol{N}$ & $\mathbf{\%}$ & $\boldsymbol{N}$ & $\mathbf{\%}$ \\
\hline $\begin{array}{l}\text { Number of respondents who made one or more } \\
\text { improvements }\end{array}$ & 122 & 59,5 & 177 & 88,5 & 299 & 73,8 \\
\hline Floor covering & 22 & 10,7 & 136 & 68,0 & 158 & 39,0 \\
\hline Security gates/burglar bars & 46 & 22,4 & 93 & 46,5 & 139 & 34,3 \\
\hline Painting the house & 51 & 24,9 & 84 & 42,0 & 135 & 33,3 \\
\hline Plastering & 49 & 23,9 & 55 & 27,5 & 104 & 25,7 \\
\hline Gardening (including vegetables) & 11 & 5,4 & 36 & 18,0 & 47 & 11,6 \\
\hline Electricity connections & 22 & 10,7 & 23 & 11,5 & 45 & 11,1 \\
\hline Doors & 22 & 10,7 & 7 & 3,5 & 29 & 7,2 \\
\hline Windows & 21 & 10,2 & 14 & 7,0 & 35 & 8,6 \\
\hline Extension of the house & 6 & 2,9 & 6 & 3,0 & 12 & 3,0 \\
\hline Total survey participants & 205 & 100 & 200 & 100 & 405 & 100 \\
\hline
\end{tabular}

TABLE 5: $\quad$ ENVISAGED IMPROVEMENTS TO BASIC HOUSING STRUCTURE IN TURFLAAGTE, 2004

\begin{tabular}{|l|c|c|c|c|c|c|}
\hline \multirow{2}{*}{ Type of improvements envisaged } & Female-headed & \multicolumn{2}{|c|}{ Male-headed } & \multicolumn{3}{|c|}{ Total } \\
\cline { 2 - 8 } & $N$ & $\%$ & $N$ & $\%$ & $N$ & $\%$ \\
\hline $\begin{array}{l}\text { Number of respondents who envisaged one or more } \\
\text { improvements }\end{array}$ & 123 & 60,0 & 179 & 89,0 & 302 & 74,6 \\
\hline Extension of the house & 83 & 40,5 & 77 & 38,5 & 160 & 39,5 \\
\hline Better house structure / repairs to walls, roof & 19 & 9,3 & 29 & 14,5 & 48 & 11,9 \\
\hline $\begin{array}{l}\text { Addition of doors, windows, electricity, plastering, } \\
\text { burglar bars }\end{array}$ & 14 & 6,8 & 34 & 17,0 & 48 & 11,9 \\
\hline Bathroom / sanitation & 7 & 3,4 & 38 & 19,0 & 45 & 11,1 \\
\hline Total survey participants & 205 & 100 & 200 & 100 & 405 & 100 \\
\hline
\end{tabular}


TABLE 6:

DEGREE OF SATISFACTION WITH BASIC SERVICES IN TURFLAAGTE, 2004

\begin{tabular}{|c|c|c|c|c|c|c|}
\hline \multirow{2}{*}{ Degree of satisfaction } & \multicolumn{2}{|c|}{ Female-headed } & \multicolumn{2}{|c|}{ Male-headed } & \multicolumn{2}{|c|}{ Total } \\
\hline & $N$ & $\%$ & $N$ & $\%$ & $N$ & $\%$ \\
\hline \multicolumn{7}{|c|}{ Water provision } \\
\hline Satisfied & 180 & 87,8 & 182 & 91,0 & 362 & 89,4 \\
\hline Not satisfied & 25 & 12,2 & 18 & 9,0 & 43 & 10,6 \\
\hline Total & 205 & 100 & 200 & 100 & 405 & 100 \\
\hline \multicolumn{7}{|c|}{ Energy (cooking, heating and lighting) } \\
\hline Satisfied & 181 & 92,5 & 158 & 81,4 & 339 & 87,0 \\
\hline Not satisfied & 15 & 7,5 & 36 & 18,6 & 51 & 13,1 \\
\hline Total & 196 & 100 & 194 & 100 & 390 & 100 \\
\hline \multicolumn{7}{|c|}{ Respondents WITH a waterborne sanitation system (functioning properly; hygienic system) } \\
\hline Satisfied & 94 & 91,3 & 90 & 90,0 & 184 & 90,6 \\
\hline Not satisfied & 9 & 8,7 & 10 & 10,0 & 19 & 9,4 \\
\hline Total & 103 & 100 & 100 & 99,5 & 203 & 100 \\
\hline \multicolumn{7}{|c|}{ Respondents WITHOUT a waterborne sanitation system (functioning properly; hygienic system) } \\
\hline Satisfied & 11 & 10,9 & 1 & 1,0 & 12 & 6,0 \\
\hline Not satisfied & 90 & 89,1 & 99 & 99,0 & 189 & 94,0 \\
\hline Total & 101 & 100 & 100 & 100 & 201 & 100 \\
\hline
\end{tabular}

* The missing values were not included in the statistic

male respondents were less satisfied with the number of rooms in their houses (Table 3), more female than male respondents $(40,5 \%$, vs $38,5 \%)$ aspired to extend their houses. This is the only aspect in respect of which more female than male respondents envisaged a significant change relating to their houses. However, even though the survey results indicated that beneficiaries sought to enlarge their houses, few respondents had actually made any extensions by the time of the survey. As indicated in Table 4 , only $2,9 \%$ of the female and $3,0 \%$ of the male respondents had added an extra room. Insufficient finances are probably the most logical explanation for the lack of expansion. An additional gender-related difference is that fewer female respondents than male respondents expressed a desire to upgrade their bathroom facilities $(3,4 \%$ vs $19,0 \%)$. The male respondents who did not have waterborne sanitation were more dissatisfied $(99,0 \%$ vs $89,0 \%$ ) with their situation than were their female counterparts, and this could be an explanation for the male respondents' greater desire to upgrade bathroom facilities (Table 6). Other desired changes correlate with improvements that some respondents had made, and include changes to the structure of the house through repairs; the addition of extra doors and windows; electricity installations; plastering; and burglar bars.

Although the respondents had made various types of improvements to their houses, and envisaged other improvements, it needs to be stressed that the study is case-specific, and that many more research studies are needed before the results with regard to improvements made and envisaged can be generalised according to gender. What is more important is the fact that considerably fewer female than male respondents had made improvements to their houses; and this correlates with previous research studies (for genderrelated examples, see Ndinda, 2002 \& 2004). In addition, our case study substantiates some general case studies conducted by Tomlinson (1999), Zack and Charlton (2003:41) and the Public Service Commission $(2003: 89,90)$ with regard to the low incidence of housing expansion.

The obvious question that arises from a gender perspective is whether one should question the incremental nature of the housing policy. However, to do so, and to reach a conclusion on the basis of our case study, would be somewhat simplistic. Rather, our argument is that post-occupancy support should be gender-sensitive, and that specific provision should be made for supplying building advice and assistance to female-headed households.

\section{The importance of policy and infrastructure}

Housing policy in the Free State stipulated the construction of housing units of at least $40 \mathrm{~m}^{2}$. This approach ensured that, on average, the Free State constructed the largest housing units (Marais, 2003:107). However, research has also indicated that this was achieved at the expense of infrastructure provision (Marais \& Krige, 2000; Marais, 2003:112). Marais (2002) also argued that this policy, which emphasises housing size while neglecting infrastructure provision, does not take into account the importance of basic infrastructure to women. In our case study area, this policy approach resulted in $50,1 \%$ of households not having a proper sanitation system available and $41,3 \%$ of households not having water inside their housing units. (Admittedly, 99,5\% of households had water on their sites.) However, in general, the lack of proper sanitation is an even more negative factor for 
TABLE 7: CHOICE BETWEEN BASIC SERVICES AND BIGGER HOUSE

\begin{tabular}{|l|c|c|c|c|c|c|}
\hline \multirow{2}{*}{ Choice between services and size of house } & \multicolumn{2}{|c|}{ Female-headed } & \multicolumn{2}{|c|}{ Male-headed } & \multicolumn{3}{|c|}{ Total } \\
\cline { 2 - 7 } & $\boldsymbol{N}$ & $\mathbf{\%}$ & $\boldsymbol{N}$ & $\mathbf{\%}$ & $\boldsymbol{N}$ & $\%$ \\
\hline Better basic services but with a smaller house & 189 & 93,1 & 175 & 90,7 & 364 & 91,9 \\
\hline Bigger house without basic services & 14 & 6,9 & 18 & 9,3 & 32 & 8,1 \\
\hline Total & 203 & 100 & 193 & 100 & 396 & 100 \\
\hline
\end{tabular}

** The missing values were not included in the statistics

women than it is for men. This also holds true in the case of Bloemfontein. In view of the outcome of the Free State housing policy, which resulted in lower levels of infrastructural services, the focus will now shift to the importance of infrastructure.

\section{Satisfaction with basic services provided}

The survey results indicated more similarities than differences between the genders in terms of satisfaction levels with regard to basic services provided.

As indicated in Table 6, compared with the degree of satisfaction with the basic structure of the house, a high level of satisfaction was noted in the case of both female and male respondents in respect of the basic services of water provision $(87,8 \%$ and $91,0 \%)$, energy provision $(92,5 \%$ and $81,4 \%)$ and the waterborne sanitation system, in the case of those respondents who had such systems $(91,3 \%$ and $90,0 \%)$. The greater level of satisfaction of female respondents with the energy services may indicate that they were able to attend to their household needs more efficiently than was the case before the services were upgraded in the Turflaagte settlement. Whereas female and male respondents with waterborne sanitation were pleased with the sanitation services $(91,3 \%$ and 90,5\%), respondents with no waterborne sanitation were very dissatisfied with the alternative methods of sanitation that they were obliged to use (Table 6 ). Only $10,9 \%$ of the female and $1 \%$ of the male respondents were satisfied, to a small degree, with the situation.

\section{Choice between basic services and bigger houses}

In view of the policy of the Free State province, households were asked whether they would prefer higher levels of infrastructure with smaller houses, or lower levels of infrastructure with bigger houses, if they were given a choice in this regard.

The results show that households place a high value on infrastructure (Table 7). There was virtually no gender difference with regard to the respondents' preference, when they were asked whether they would choose a smaller house with better services, or a bigger house with fewer services. Given the choice between a bigger house, on the one hand, and a better level of infrastructure, on the other, $93,1 \%$ of female, and $90,7 \%$ of male respondents would choose a smaller house with a better level of infrastructure. Thus, even though a large number of respondents envisaged enlarging their houses, both female and male respondents would have preferred a smaller house with better services.

The preference for better infrastructure correlates with the findings of other studies (Public Service Commission, 2003:97; Zack \& Charlton, 2003:58), in which households provided with lower levels of services expressed dissatisfaction with their infrastructure, and respondents indicated that they attached great importance to the infrastructure. In view of the importance of infrastructure, as demonstrated above, the current $40 \mathrm{~m}^{2}$ housing policy - which results in lower levels of infrastructure - should be reconsidered or adjusted, in order to also cater for a fair level of infrastructure.

\section{CONCLUSION}

In this article, the application of gender-sensitivity in the South African housing policy context has been assessed against international changes in respect of gender and housing paradigms. In line with international and national literature, the greatest genderrelated difference was observed in the socio-economic statuses of the respondents. Since the survey results clearly indicated that female beneficiaries are poorer, and have less income and formal education than male respondents, policy interventions to address the situation are necessary. As a result, the aim of current housing policy, namely a shift towards a more integrated, whole-sector development, taking the social and economic aspects into account in housing projects, has only partially been achieved in practice. Moreover, an analysis of the housing subsidy scheme, together with our case study, reveals that women's needs are not sufficiently being taken into consideration in terms of the incremental nature of the housing policy. Female low-income earners, especially in single-headed, female-headed households, do not have the same levels of economic means and physical ability as men, to allow them to participate equally in the incremental housing process. In addition, the case study indicates that the construction of substandard low-income houses still persists, and that the physical attributes and flaws of the low-income houses are more severely and negatively experienced by respondents from female-headed households. Although the issues of better building standards and adequate quality control are addressed in the housing policy, poor construction has persisted since the beginning of the housing subsidy allocation. On the other hand, as far as quality is concerned, it is very difficult to construct a 
high-quality house by means of the current housing subsidy. Lastly, the survey also indicated that both female and male respondents attach a greater value to the provision of basic services than to housing size. Consequently, the current $40 \mathrm{~m}^{2}$ housing policy of the Free State province, which results in lower levels of infrastructure, should be reconsidered in order to provide for a better level of infrastructure.

\section{LIST OF REFERENCES}

ABERCROMBIE, N, HILL, S \& TURNER, B. 2000. The Penguin Dictionary of Sociology. 4th ed. England. Penguin Books.

BEALL, J. 1996. Participation in the city: where do women fit in? Gender and Development 4(1):9-16.

BEALL, J \& TODES, A. 2004. Gender and integrated area development projects: lessons from Cato Manor, Durban. Cities 21(4):301-310.

BENSCHOP, M. 2004. Women's rights to land and property. Nairobi. UN-Habitat.

BERRISFORD, S, KIHATO, M \& KLUG, N. 2003. Element Two: International shifts in shelter and settlement policy and their implication for South African praxis. Report prepared for USAID/South Africa's Strategic Objective No. 6: Increased Access to Shelter and Environmentally Sound Municipal Services. Pretoria. Mega-Tech, Inc.

BOND, P \& TAIT, A. 1997. The failure of housing policy in post-apartheid South Africa. Urban Forum 8 (1):21-42.

BUDLENDER, D. 2001. Gender, development and infrastructure. In Khosa, M (ed). Infrastructure mandates for change, 1994-1999. Pretoria. Human Science Research Council.

CHANT, S. 2003a. Female household headship and the feminisation of poverty: facts, fictions and forward strategies. New Working Paper Series. Issue 9. London. School of Economics. Gender Institute.

CHANT, S. 2003b. New contributions to the analysis of poverty: methodological and conceptual challenges to understanding poverty from a gender perspective. Santiago. Women and Development Unit. United Nations.

DEPARTMENT OF HOUSING. 2003. Housing Statistics 1994 to January 2003. Pretoria. Available on line. URL: http://www.housing.gov.za/Content/planned/ Docs/Housing\%20Delivery\%20Jan\%202003.pdf\#search $=\% 22$ Housing $\% 20$ Statistics $\% 201994 \% 20$ to\% 20January\%202003\%22. Accessed 3 February 2005. DEPARTMENT OF HOUSING. 2004. "Breaking New Ground" - A Comprehensive Plan for the Development of Sustainable Human Settlements. Pretoria.

FAHRA, L. 1999. Is there a woman in the house? Women and the right to adequate housing. A resource guide to women's international human rights. New York. Transnational Publishers.

FREE STATE DEPARTMENT OF LOCAL GOVERNMENT AND HOUSING. 2004. Mangaung Housing Policy Draft. Bloemfontein.

GILBERT, A. 2002. "Scan globally; reinvent locally": reflecting on the origins of South Africa's Capital Housing Subsidy Policy. Urban Studies 39(10):19111933.
GILBERT, A. 2004. Helping the poor through housing subsidies: lessons from Chile, Colombia and South Africa. Habitat International 28:13-40.

HARRIS, R. 2003. A double irony: the originality and influence of John FC Turner. Habitat International 27:254-269.

KEIVAN, R \& WERNA, E. 2001. Refocusing the housing debate in developing countries from a pluralist perspective. Habitat International 25:91-208.

KHAN, F \& THURMAN, S. 2001. Setting the stage: current housing policy and debate in South Africa. Cape Town. Isandla Institute.

KOTHARI, M. 2003. Workshop on Gender Perspectives on the Right to Adequate Housing. Overview of the UN special rapporteur on right to adequate housing's mandate and work to date. Thailand, 10 June. LATIGO, A. 2004. The missing link in growth and sustainable development: closing the gender gap. Symposium on Gender Growth and Sustainable Development, 24 May. Uganda. African Development Bank and Economic Commission for Africa.

MARAIS, L. 2002. Gender issues in housing delivery in the Free State since 1994. Acta Academia Supplementum 1:147-166.

MARAIS, L. 2003. Low-income housing in the postapartheid era: towards a policy framework for the Free State. Unpublished PhD thesis. Bloemfontein. University of the Free State.

MARAIS, L \& KRIGE, S. 2000. Who received what, where in the Free State? An assessment of postapartheid housing delivery and policy (1994-98). Development Southern Africa 17(4):603-618.

MARX, C. 2003. Supporting informal settlements. In Khan, F \& Thring (eds). Housing policy and practice in post-apartheid South Africa. Sandton. Heineman Publishers.

MEHLOMAKULU, T \& MARAIS, L. 1999. Dweller perceptions of public and self-built houses: some evidence from Mangaung (Bloemfontein). Journal of Family Ecology and Consumer Sciences 27 (2): 92102.

MOSER, CON. 1987. Women, human settlements and housing: a conceptual framework for analysis and policy-making. In Moser, CON \& Peake, L. (eds). 1987. Women, human settlement, and housing. London. Tavistock.

MOSER, CON \& PEAKE, L. 1994. Seeing the invisible: women, gender and urban development. Urban research in the developing world. Major Report No. 30. Toronto. Center for Urban and Community Studies. University of Toronto.

NDINDA, C. 2002. Women's participation in housing delivery in South Africa: the extent of empowerment with reference to case studies in KwaZulu-Natal. Unpublished PhD thesis. Durban. University of Natal. NDINDA, C. 2004. "Sweat equity": women's participation in subsidised housing in South Africa. Africa Insight 34(2/3),58-64.

NIENTIED, P \& VAN DER LINDE, J. 1985. Approaches to low-income housing in the Third World: some comments. International Journal of Urban and Regional Research 9(3),311-329.

ORGANISATION FOR ECONOMIC CO-OPERATION AND DEVELOPMENT (OECD). 1995. Women in the city, housing, services and the urban environment. 
Paris. OECD.

PETERS, C. 1996. Interview: Chris Peters talks to Catalina Hinchey Trujillo, about her work for the UN Agency Habitat. Gender and Development 4(1):53-56. PUBLIC SERVICE COMMISSION. 2003. Report on the evaluation of the National Housing Subsidy Scheme. Pretoria.

PUGH, C. 1991. Housing policies and the role of the World Bank. Habitat International 15(1/2):275-298.

PUGH, C. 1997. Poverty and progress? Reflections on housing and urban policies in developing countries, 1976-96. Urban Studies 34(10):1547-1595.

PUGH, C. 2001. The theory and practice of housing sector development for developing countries, 195099. Housing Studies 16(4):399-423.

RAKODI, C. 1996. Women in the city of man: recent contributions to the gender and human settlements debate. Gender and Development 4(1):57-59.

REPUBLIC OF SOUTH AFRICA. 1994. White Paper on Housing: a new housing policy and strategy for South Africa. Pretoria. Government Printer.

RICHARDS, K \& RUST, K. 2002. Evaluation: women and housing policy. Policy and programme review. Johannesburg. Department of Housing. Gauteng Provincial Government.

STATISTICAL PACKAGE FOR THE SOCIAL SCI-
ENCES (SPSS). 2003. SPSS Version 12.0 statistical software. Chicago.

STATISTICS SOUTH AFRICA. 1998. The people of South Africa population. Census, 1996 database. Pretoria. Statistics South Africa.

STATISTICS SOUTH AFRICA. 2003. Community profiles. Census, 2001 database. Pretoria. Statistics South Africa.

STATISTICS SOUTH AFRICA. 2004. Census, 2001. Concepts and definitions. Pretoria. Statistics South Africa.

SWEETMAN, C. 1996. Editorial. Gender and Development 4(1):2-8.

TOMLINSON, M. 1999. From rejection to resignation: beneficiaries' views on the South African government's new housing subsidy system. Urban Studies 36:1349-1359.

UNITED NATIONS CENTRE FOR HUMAN SETTLEMENTS (UNCHS). 2000. Draft policy paper on women and urban governance. Nairobi. UNCHS.

WICKRAMASINGHE, M. 2000. From theory to action: women, gender and development. Colombo. Friedrich-Ebert-Stiftung.

ZACK, T \& CHARLTON, S. 2003. Better off, but ... beneficiaries' perceptions of the government's housing subsidy scheme. Johannesburg. Housing Finance Resource Programme. 